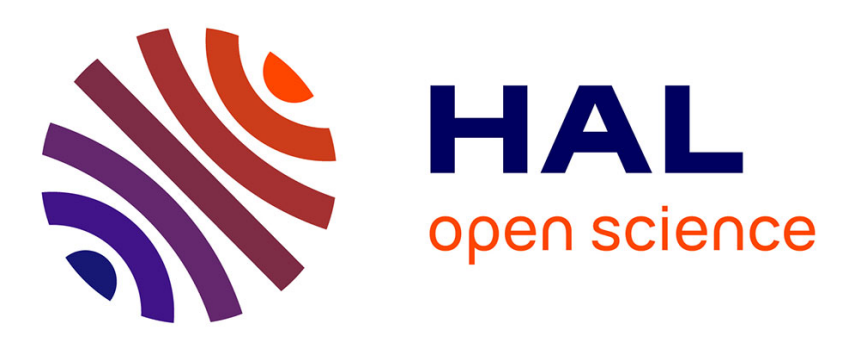

\title{
Glucocerebrosidase deficiency and mitochondrial impairment in experimental Parkinson disease
}

\author{
Carmen Noelker, Lixia Lu, Matthias Höllerhage, Franca Vulinovic, \\ Annekathrin Sturn, René Roscher, Günter U Höglinger, Etienne C Hirsch, \\ Wolfgang H Oertel, Daniel Alvarez-Fischer, et al.
}

\section{To cite this version:}

Carmen Noelker, Lixia Lu, Matthias Höllerhage, Franca Vulinovic, Annekathrin Sturn, et al.. Glucocerebrosidase deficiency and mitochondrial impairment in experimental Parkinson disease. Journal of the Neurological Sciences, 2015, 356 (1-2), pp.129-136. 10.1016/j.jns.2015.06.030 • hal-01166888

\section{HAL Id: hal-01166888 \\ https: / hal.sorbonne-universite.fr/hal-01166888}

Submitted on 23 Jun 2015

HAL is a multi-disciplinary open access archive for the deposit and dissemination of scientific research documents, whether they are published or not. The documents may come from teaching and research institutions in France or abroad, or from public or private research centers.
L'archive ouverte pluridisciplinaire HAL, est destinée au dépôt et à la diffusion de documents scientifiques de niveau recherche, publiés ou non, émanant des établissements d'enseignement et de recherche français ou étrangers, des laboratoires publics ou privés. 


\title{
Glucocerebrosidase deficiency and mitochondrial impairment in experimental Parkinson disease
}

\author{
Carmen Noelker ${ }^{1,2,3,4}$, Lixia Lu ${ }^{1,2,3}$, Matthias Höllerhage ${ }^{4,8,9}$, Franca Vulinovic ${ }^{6}$, Annekathrin \\ Sturn $^{4}$, René Roscher ${ }^{5}$, Günter U. Höglinger ${ }^{4,8,9}$, Etienne C. Hirsch ${ }^{1,2,3}$, Wolfgang H. Oertel ${ }^{4}$, \\ Daniel Alvarez-Fischer ${ }^{* 1,2,3,6,7}$ and Andreas Hartmann ${ }^{* 1,2,3}$
}

\footnotetext{
${ }^{1}$ INSERM, CR-ICM, UMR_S1127, 75013 Paris, France

${ }^{2}$ Université Pierre et Marie Curie Paris 06 UMR_S975, 75013 Paris France

${ }^{3}$ CNRS, UMR 7225, CR-ICM, Groupe Hospitalier Pitié-Salpêtrière, 75013 Paris, France, ${ }^{4}$ Department of Neurology, Faculty of Medicine, Philipps-University, Marburg, Germany;

${ }^{5}$ Actelion Pharmaceuticals Ltd, 4123 Allschwil, Switzerland

${ }^{6}$ Institute of Neurogenetics, University of Luebeck, 23562 Luebeck, Germany

${ }^{7}$ Department of Psychiatry, University of Luebeck, 23562 Luebeck, Germany

${ }^{8}$ Department of Neurology, Technical University Munich, Germany.

${ }^{9}$ Deptartment of Translational Neurodegeneration, German Center for Neurodegenerative

Diseases (DZNE), Munich, Germany.

${ }^{*}$ Both authors contributed equally
}

\author{
Corresponding author: \\ Andreas Hartmann, MD \\ Institut du cerveau et de la moelle épinière, ICM \\ CR-ICM, INSERM UMR_S1127, CNRS UMR 7225 \\ Groupe Hospitalier Pitié-Salpêtrière \\ 47-83 Boulevard de l'Hôpital \\ 75651 Paris Cedex 13 \\ France \\ Tel. +33 (0)157274556 \\ Fax +33 (0)157274782 \\ Email: andreas.hartmann@psl.aphp.fr
}

Running title : Glucerebrosidase and PD 


\section{ABStRAct}

Gaucher disease is an autosomal recessive disease, caused by a lack or functional deficiency of the lysosomal enzyme, glucocerebrosidase (GCase). Recently, mutations in the glucocerebrosidase gene (GBA) have been associated with Parkinson disease (PD) and GBA mutations are now considered the most important genetic vulnerability factor for PD. In this study, we have investigated (i) in vivo whether inhibition of the enzyme glucosylceramide synthase by miglustat may protect C57BI/6 mice against subchronic 1-methyl-4-phenyl1,2,3,6-tetrahydropyridine (MPTP) intoxication and (ii) in vitro whether a decrease of GCase activity may render dopaminergic neurons susceptible to MPP $^{+}$(1-methyl-4phenylpyridinium) or alpha-synuclein ( $\alpha-S y n)$ toxicity and amenable to miglustat treatment. We could demonstrate that reduction of glucocerebroside by inhibition of glucosylceramide synthase partially protects mice against MPTP-induced toxicity. Conversingly, we could show that inhibition of GCase activity with conduritol-B-epoxide (CBE) enhances both $\alpha$-Syn and $\mathrm{MPP}^{+}$induced toxicity in vitro. However, only CBE-induced enhancement of $\mathrm{MPP}^{+}$toxicity could be reversed by miglustat. Moreover, we were unable to reveal any alterations of complex I activity or cell respiration upon treatment with either CBE or miglustat. Our findings suggest that the reduction of GCase activity rather than an accumulation of glucocerebroside increases aSyn toxicity.

Key words: Glucocerebrosidase, Gaucher disease, Parkinson disease, dopamine cell death, MPTP, a-Syn, mitochondria.

\section{Abbreviations:}

a-Syn, alpha-Synuclein; CBE, conduritol-B-epoxide; CCCP, carbonyl cyanide 4(trifluoromethoxy)phenylhydrazone; CS, citrate synthase; Cx I, Mitochondrial respiratory chain complex I; DA, dopaminergic; DIV, day in vitro; DMSO, dimethyl sulfoxide; EDTA, ethylene diamine tetraacetic acid; ECAR, extracellular acidification rate; GBA, glucocerebrosidase gene; GCase : glucocerebrosidase; GDNF, Glial cell-derived neurotrophic factor; HPLC, high-performance liquid chromatography; HVA, homovanillic acid; LB, Lewy bodies; LDH, lactate dehydrogenase; LUHMES, Lund human mesencephalic cell line; MPP+, 1-methyl-4-phenylpyridinium; MPTP, 1-methyl-4-phenyl-1,2,3,6tetrahydropyridine; NeuN, neuronal nuclei; OCR, oxygen consumption rate; PBS, phosphate buffered saline; PD, Parkinson disease; PFA, paraformaldehyde; SH-SY5Y, human neuroblastoma cell line; SNpc, substantia nigra pars compacta; $\mathrm{TH}$, tyrosine hydroxylase. 


\section{INTRODUCTION}

Gaucher disease is an autosomal recessive disease, caused by a lack or functional deficiency of the lysosomal enzyme, glucocerebrosidase (GCase), which catalyses the breakdown of glucocerebroside to glucose and ceramide [1]. One therapeutic approach is the treatment with $\mathrm{N}$-butyldeoxynojirimycin, known as miglustat, an imino sugar that inhibits glucosylceremide synthase, a glucosyl transferase enzyme responsible for the first step in the synthesis of most glycosphingolipids, including glucosylceramide (Fig. 1). Thereby, miglustat reduces intracellular storage of glucosylceramide. Recently, mutations in the glucocerebrosidase gene (GBA) have been associated with Parkinson disease (PD), a common neurodegenerative disorder characterized clinically by akinesia, rigidity and rest tremor. The cardinal neuroanatomical feature of $P D$ is a massive and preferential loss of dopaminergic (DA) neurons in the substantia nigra pars compacta (SNpc), resulting in a drastic decline in striatal dopamine concentrations. Additionally, aggregates of fibrillated alpha-synuclein ( $\alpha-S y n)$ are the major component of so-called Lewy bodies (LB) which are the pathologic hallmarks of PD $[2,3]$.

In a large multicenter study, $3 \%$ of patients with PD, so far classified as 'idiopathic', displayed the frequent N370S or L444P GBA mutations [4]. When taking into consideration rarer mutations, this figure has been estimated to rise to $7 \%$ [5]. Moreover, this association appears not to be restricted to Ashkenazi Jews, as initially suggested [6], but is present worldwide in a multitude of ethnicities; thus, GBA mutations can be considered the most important genetic vulnerability factor for PD identified to date [7-9]. Interestingly, in the substantia nigra of sporadic PD patients without GBA mutations, GCase deficiency could be demonstrated very recently [10], lending support to the notion that GCase function may be altered in synucleinopathies [11, 12]. Conversely, dysfunction of GCase has been shown to increase the levels of intracellular a-Syn [13-15]. However, the mechanism underlying these findings remains unclear to date. Different hypotheses have been raised including a gain-ofnovel-function model contributing to the enhanced aggregation of $\alpha$-Syn either by a direct or indirect interaction between GCase and a-Syn. 
In the present, proof-of-concept study, we have investigated in vivo whether inhibition of the enzyme glucosylceramide synthase by miglustat may protect mice against intoxication with MPTP (1-methyl-4-phenyl-1,2,3,6-tetrahydropyridine), a neurotoxin selectively targeting dopaminergic neurons. Based on our in vivo results, we have further attempted to clarify in vitro whether a decrease of GCase activity may render dopaminergic neurons more susceptible to $\mathrm{MPP}^{+}$(1-methyl-4-phenylpyridinium), the active metabolite of MPTP, or $\alpha$-Synmediated toxicity, and if inhibition of glucosylceramide synthase also protects dopaminergic neurons under these conditions.

\section{Figure 1:}

Glycosphingolipids

Ganglio-series Globo-series

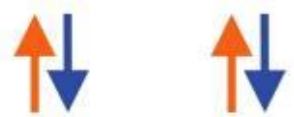

Glucosylceramide

Miglustat $\longrightarrow \begin{aligned} & \text { Glucosylceramide } \\ & \text { Synthase }\end{aligned}$

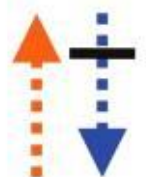

Galactosylceramide

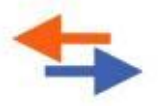

Ceramide
Glucocerebrosidase deficiency (Gaucher)
Sphingomyelin

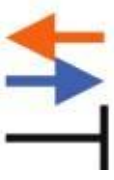

Synthesis

Degradation

Inhibition

Inhibition of glucosylceramide synthesis with miglustat by Can Ficicioglu [16] 


\section{MATERIALS AND MethodS}

\subsection{Animals}

Animals were housed, handled, and cared for in accordance with the Guide for the Care and Use of Laboratory Animals [NCR (National Research Council) 1996] and the European Union Council Directive 86/609/EEC, and the experimental protocols were carried out in compliance with institutional ethical committee guidelines for animal research. All efforts were made to minimize the number of animals used and their suffering. For all studies, mice were maintained on a $12: 12 \mathrm{~h}$ light/dark cycle with lights on at 6.30 a.m. The room temperature was kept at $23^{\circ} \mathrm{C}$, with free access to standard diet and tap water.

\subsection{Subchronic MPTP intoxication of mice and miglustat treatment}

Nine week old male C57/BI6 mice (Janvier Breeding Center, France) were used ( $n=8-10$ per group). The mice were injected i.p. with either $30 \mathrm{mg} / \mathrm{kg} \mathrm{MPTP}-\mathrm{HCl}$ once daily for a total of 5 days or a corresponding volume of $\mathrm{NaCl} 0.9 \%$ [17]. For miglustat treatment, the mice were fed 3 times daily by gavage ( $840 \mathrm{mg} / \mathrm{kg}$ body weight) or a corresponding volume of saline, respectively resulting in the following treatment groups of mice: saline treated control animals fed with either miglustat or saline $(\mathrm{NaCl} 0.9 \%)$ gavage $(\mathrm{NaCl} 0.9 \%$ / miglustat or $\mathrm{NaCl}$ $0.9 \% / \mathrm{NaCl} 0.9 \%)$ or mice treated intoxicated with MPTP receiving miglustat or saline $(\mathrm{NaCl}$ $0.9 \%$ ) gavage (MPTP/miglustat, MPTP/NaCl 0.9\%).

Miglustat administration was started one day after the MPTP intoxications and continued until sacrifice 7 days after the end of intoxications. Subsequently, the animals were killed by cervical dislocation and their brains were processed for further analysis.

All systemic injections were administered through the intraperitoneal route and the neurotoxins were dissolved in saline. All procedures involving MPTP injections in mice were performed according to standard procedures [18].

\subsection{Neurochemical analysis}


The striatum of the animals was used for high-performance liquid chromatography (HPLC) measurement of DA and homovanillic acid (HVA). Dopamine was analysed by reversed phase chromatography combined with a two-channel electrochemical detector under isocratic conditions as previously described [19]. Briefly, detector potential was set at +750 $\mathrm{mV}$ using a glassy carbon electrode and an $\mathrm{Ag} / \mathrm{AgCl}$ reference electrode. The mobile phase (0.14 $\mathrm{g}$ octanesulfonic acid sodium salt, $0.1 \mathrm{~g} \mathrm{Na}_{2}$ EDTA, $6 \mathrm{ml}$ triethylamine, adjusted to $\mathrm{pH}$ 2.8 with $\mathrm{H}_{3} \mathrm{PO}_{4}$ in $1 \mathrm{I}$ millipore $\mathrm{Q}$ water containing $35 \mathrm{ml}$ acetonitrile) was delivered at a rate of $0.5 \mathrm{ml} / \mathrm{min}$ at $22^{\circ} \mathrm{C}$ onto the reversed phase column $(125 \times 3 \mathrm{~mm}$ with pre-column $5 \times 3 \mathrm{~mm}$; Nucleosil 120-3 C18; Knauer, Berlin, Germany). Twenty-microliter aliquots were injected by an autosampler with the cooling module set at $4^{\circ} \mathrm{C}$.

\subsection{Immunohistochemistry}

The posterior part of the brains was postfixed with $4 \%$ paraformaldehyde (PFA) and cryoprotected. Immunohistochemistry was performed as described previously [20] on freefloating cryomicrotome-cut sections $(20 \mu \mathrm{m})$ encompassing the entire midbrain. Sections were incubated with a rabbit polyclonal antibody against tyrosine hydroxylase $(\mathrm{TH} ; 1: 1000$; Pel-Freez Biologicals, Rogers, AR). Sections were then treated with secondary antibodies (Vectastain, Vector Laboratories, Burlingame, CA) and subsequently incubated with avidinbiotinylated horseradish peroxidase complex. Peroxidase was revealed by incubation with $0.05 \% 3,3$ '-diaminobenzidine tetrahydrochloride containing $0.008 \%$ hydrogen peroxide. Sections were Nissl counter-stained (for details see [21]).

\subsection{Cell counting in vivo}

Quantification was performed as described previously [21]. Tyrosine hydroxylase-positive neurons were visualized in bright field (Nikon Optiphot-2) and quantified stereologically on regularly spaced sections covering the mesencephalon from the rostral pole of the SNpc to the locus coeruleus (Mercator T4.18 stereology software). The SNpc was identified 
according to established anatomical landmarks [22]. Cell loss was verified by Nissl counterstaining.

\subsection{Primary mesencephalic cell cultures}

For mouse mesencephalic cultures, E 13.5 Swiss mouse embryos were used (Janvier Breeding Center). The dissected tissue pieces were processed according to previously described protocols [23, 24]. Briefly, after mechanical dissociation in modified L15 medium with no enzymatic treatment, the cells were plated at a density of $1.5-2.0 \times 10^{5} \mathrm{cells} / \mathrm{cm}^{2}$. The cells were then allowed to mature and differentiate in N5 culture medium [24], supplemented with $5 \%$ horse serum and $0.5 \%$ fetal calf serum except for the first 3 days in vitro (DIV), when the concentration of FCS was raised to $2.5 \%$. Ara-C $(2 \mu \mathrm{m})$ was added to the medium at DIV 1-2 after plating to inhibit proliferation of non-neuronal cells (astrocytes, microglia), as well in the presence of $1 \mu \mathrm{M}$ MK-801 to prevent secondary excitotoxic stress [25]. Mesencephalic cultures were treated either with $1 \mu \mathrm{M} \mathrm{MPP}^{+}$(Sigma-Aldrich) at DIV 4 and DIV 5 as previously described [26] combined with $50,100,200$ or $400 \mu \mathrm{M}$ conduritol-Bepoxide (CBE; Sigma-Aldrich) at DIV 1-10 or in combination of both. The cultures were left to recover until DIV 10 in the presence of control medium

\section{7. $\alpha$-synuclein overexpression in LUHMES cells}

Experiments on $\alpha$-Syn overexpression were done in LUHMES cells, transduced with adenoviral vectors to overexpress human wild-type $\alpha-S y n$ and untransduced cells for control conditions respectively [27]. LUHMES cells were cultured in Nunclon $\Delta$ Surface (Nunc, Roskilde, Denmark) plastic cell culture flasks and multi-well plates pre-coated with 0.1 $\mathrm{mg} / \mathrm{mL}$ poly-L-lysine and $5 \mu \mathrm{g} / \mathrm{mL}$ fibronectin (Sigma-Aldrich). Proliferation medium consisted of Dulbecco's modified Eagle's medium/F12 (Sigma-Aldrich), 1\% N-2 supplement (Life Technologies, Carlsbad, CA, USA), and $40 \mathrm{ng} / \mathrm{mL}$ recombinant basic fibroblast growth factor (R\&D Systems, Minneapolis, MN, USA). LUHMES cells were grown at $37^{\circ} \mathrm{C}$ in a humidified $95 \%$ air, $5 \% \mathrm{CO}_{2}$ atmosphere. Proliferating cells were enzymatically dissociated with trypsin 
(138 mM NaCl, $5.4 \mathrm{mM} \mathrm{KCl,} 6.9 \mathrm{mM} \mathrm{NaHCO3,} 5.6 \mathrm{mM}$ D-Glucose, $0.54 \mathrm{mM}$ EDTA, $0.5 \mathrm{~g} / \mathrm{L}$ trypsin from bovine pancreas type-II-S; Sigma-Aldrich) and passaged 1:10 when they reached $80 \%$ confluence. For differentiation the cells were transferred to multi-well plates at a density of $55,000 / \mathrm{cm}^{2}$ in growth medium and 24 hours after plating the medium was exchanged to differentiation medium, consisting of Dulbecco's modified Eagle's medium/F12 (Sigma-Aldrich), $1 \% \mathrm{~N}-2$ supplement (Life Technologies), $1 \mu \mathrm{g} / \mathrm{ml}$ tetracycline (SigmaAldrich), $0.49 \mathrm{mg} / \mathrm{ml}$ dibutyryl cyclic AMP (Sigma-Aldrich), and $2 \mathrm{ng} / \mathrm{ml}$ GDNF (R\&D Systems). Virus transduction was performed 48 hours into the differentiation process at an multiplicity of infection of 5 as previously described [27].

\subsection{Immunocytochemical procedures in vitro}

Primary mesencephalic cell cultures were fixed for $15 \mathrm{~min}$ at room temperature with $4 \%$ PFA and washed three times with PBS. For primary mesencephalic cell cultures, survival of DA neurons was determined by $\mathrm{TH}$ immunocytochemistry. The cultures were first incubated for $24 \mathrm{~h}$ at $4^{\circ} \mathrm{C}$ with a rabbit-polyclonal anti-TH antibody (Pel-Freez Biologicals) diluted 1:1000 in PBS containing $0.2 \%$ Triton $\mathrm{X}-100$, then incubated for $1 \mathrm{~h}$ at room temperature with an antirabbit IgG Alexa488 conjugate (1:500; Sigma/RBI). Mesencephalic cultures contained between 1 and $2 \% \mathrm{TH}+$ cells at the time of plating [23]. All neuronal cells, regardless of their neurotransmitter phenotype, were identified by staining of neuronal nuclei with a monoclonal biotin conjugated antibody anti-neuronal nuclei (NeuN) (MAB-377B, Chemicon, Temecuka, CA, USA) diluted 1:100 and a secondary antibody (biotin conjugated, Invitrogen, 1:500 in PBS and $5 \%$ horse serum).

\subsection{Quantification of in vitro neuron survival}

Survival of mesencephalic DA neurons was quantified by counting the number of tyrosine hydroxylase-positive neurons in primary cultures. Survival of LUHMES cells was quantified by the measurement of LDH released into the cell culture medium, using the CytotoxOne Membrane Integrity Assay (Promega, Fitchburg, WI, USA) according to the manufacturer's 
instructions as previously described. Data were normalized to LDH levels measured in a-Syn overexpressing cells. Positive controls were cells lysed with $10 \%$ Triton $\mathrm{X}$ in water as lysis buffer.

\subsection{Measurement of cell respiration}

Respiration was analyzed using Seahorse Biosciences technology as described elsewhere [28]. To this end, SH-SY5Y (p3-p7) cells [29] (human neuroblastoma cell line) were maintained in Dulbecco's modified Eagle's medium (DMEM; Gibco, France) supplemented with $15 \%$ fetal calf serum (FCS), $1 \mathrm{mM}$ L-glutamine, $100 \mathrm{U}$ of penicillin/ml, and $100 \mu \mathrm{g}$ of streptomycin sulfate/ml and equilibrated with $5 \% \mathrm{CO}_{2}-95 \%$ air at $37^{\circ} \mathrm{C}$. In brief, a Seahorse 24-well plate was seeded with approximately 300,000 SH-SY5Ycells/per well. At the day of plating, a fourth of the wells was treated with $800 \mu \mathrm{mol} C B E, 100 \mu \mathrm{mol}$ miglustat, the same volume of vehicle (PBS), and $100 \mu \mathrm{mol}$ miglustat followed one hour later by $800 \mu \mathrm{mol} C B E$, respectively for 24 hours. After 24 hours, wells were processed to measure oxygen consumption rate (OCR) to quantify mitochondrial respiration and the extracellular acidification rate (ECAR), an indicator of glycolysis. After determining the basal respiration in the cells, oligomycin $(2 \mu \mathrm{M})$, carbonyl cyanide 4-(trifluoromethoxy)phenylhydrazone (CCCP, $0.5 \mu \mathrm{M})$ and potassium cyanide $(2 \mathrm{mM})$ were sequentially added to the media and the OCR and ECAR was quantified for each well in parallel. Data were expressed as $\%$ of baseline. The results from three independent plates with each 5-6 wells per condition were grouped.

\subsection{Measurement of Complex I activity}

Mitochondrial respiratory chain complex I (Cx I) and citrate synthase (CS) activity were measured as previously described [30, 31]. In brief, SH-SY5Y were cultured as described above. Cells were treated with $800 \mu \mathrm{mol}$ CBE, $100 \mu \mathrm{mol}$ miglustat, the same volume of vehicle (PBS), and $100 \mu \mathrm{mol}$ miglustat followed one hour later by $800 \mu \mathrm{mol} C B E$, respectively for 48 hours. After 48 hours, cells were homogenized in homogenization buffer (250 mM sucrose, $10 \mathrm{mM}$ Tris, $\mathrm{pH}$ 7.4, $1 \mathrm{mM}$ EDTA), nuclei and cell debris were removed by 
centrifugation at $1,500 \mathrm{~g}$, and mitochondria were isolated by centrifugation at $11,800 \mathrm{~g}$. The mitochondrial pellet was then resuspended in homogenization buffer. Cx I and CS activities were measured by spectrophotometric methods in these mitochondrial preparations as reported [30,31]. Data were expressed as ratios of Cx I/CS activity in \% of control. Analysis was performed in four independent runs.

\subsection{Statistical analysis}

Data are expressed as the percent of corresponding control values. Each data point represents mean \pm S.E.M. Multiple comparisons against a single reference group were performed by one-way ANOVA followed by a post-hoc Dunnett's test. When pairwise comparisons were carried out, one-way ANOVA was followed by a post-hoc StudentNewman-Keuls test. The null hypothesis was rejected at an a risk of $5 \%$. All in vitro experiments were performed in triplicates at least, with a minimum of three wells per experimental condition. 


\section{RESULTS}

\subsection{Miglustat protects nigral DA cell bodies in MPTP-intoxicated mice}

First, we tested whether reduction of glucocerebroside by inhibition of glucosylceramide synthase upon miglustat treatment may protect mice against MPTP in a subchronic intoxication protocol. MPTP-induced $\mathrm{TH}+$ cell loss in the $\mathrm{SN}$ was $25 \pm 1.7 \%$. In mice treated orally thrice daily with miglustat, $\mathrm{TH}+$ cell loss was reduced to $12.4 \pm 2.7 \%(p<0.05)$ (Fig. 2A/B). Since the number of Nissl-positive/TH-negative neurons did not increase in MPTPtreated animals, the decrease in TH-positive neurons could be attributed to cell loss rather than loss of $\mathrm{TH}$ protein expression (percentage of $\mathrm{TH}$-negative and Nissl-positive neurons in SNpc: miglustat-treated mice $(96.3 \% \pm 7.2 \%)$, saline-treated mice $(94.9 \% \pm 8.6 \%)$. However, striatal dopamine concentrations and HVA/DA ratios remained unaffected by miglustat treatment (Fig. $3 \mathbf{A} / \mathbf{B})$, suggesting that protection did not extend to synaptic terminals.

Figure 2A/B: Miglustat protects nigral DA cell bodies in MPTP-intoxicated mice

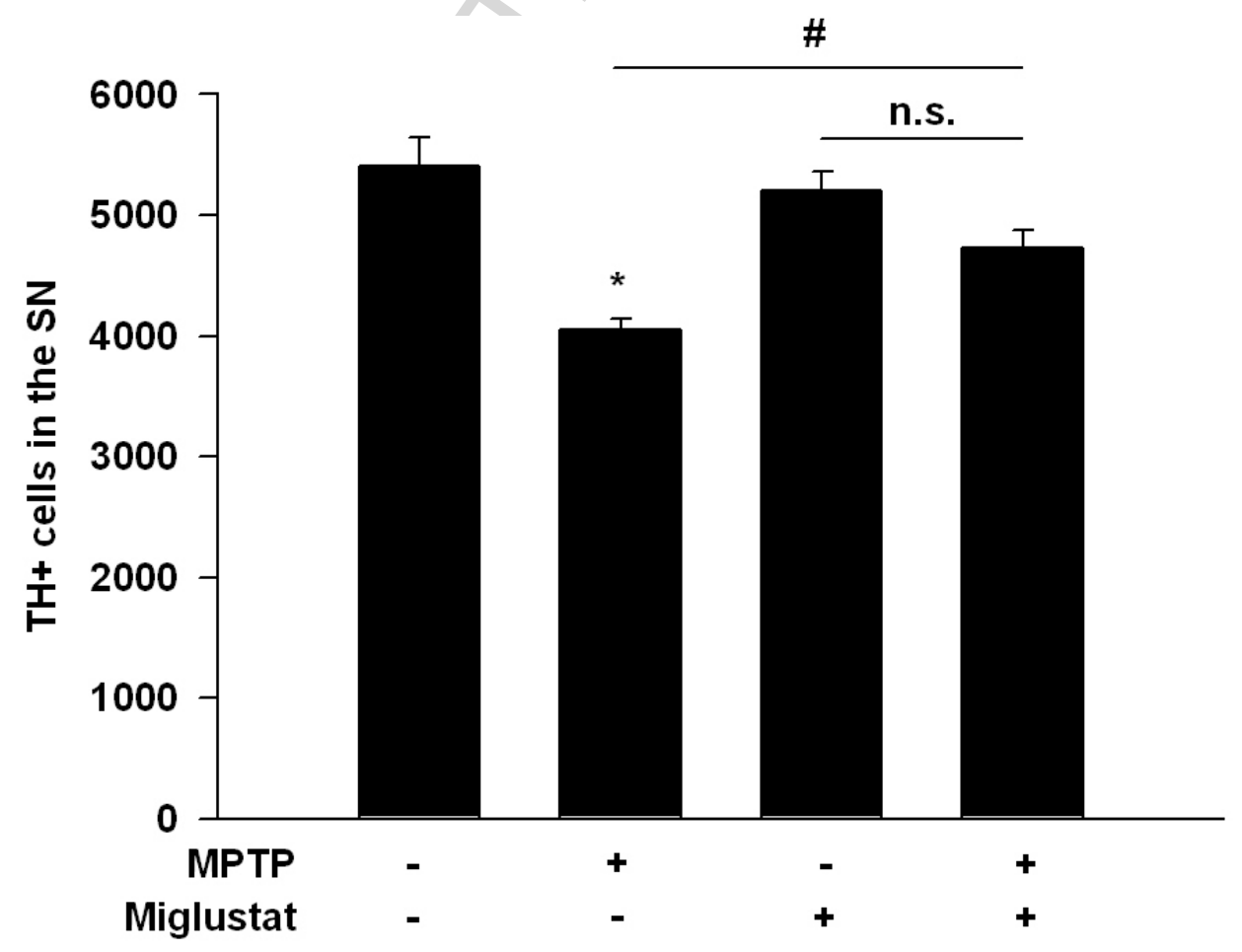

2A: Effects of miglustat treatment on subchronic MPTP induced nigral dopaminergic cell death. Data are expressed as percent of corresponding control values and represent mean \pm S.E.M. ${ }^{*} p<0.05$ compared to control values, $\# p<0.05$ for pairwise comparison. 

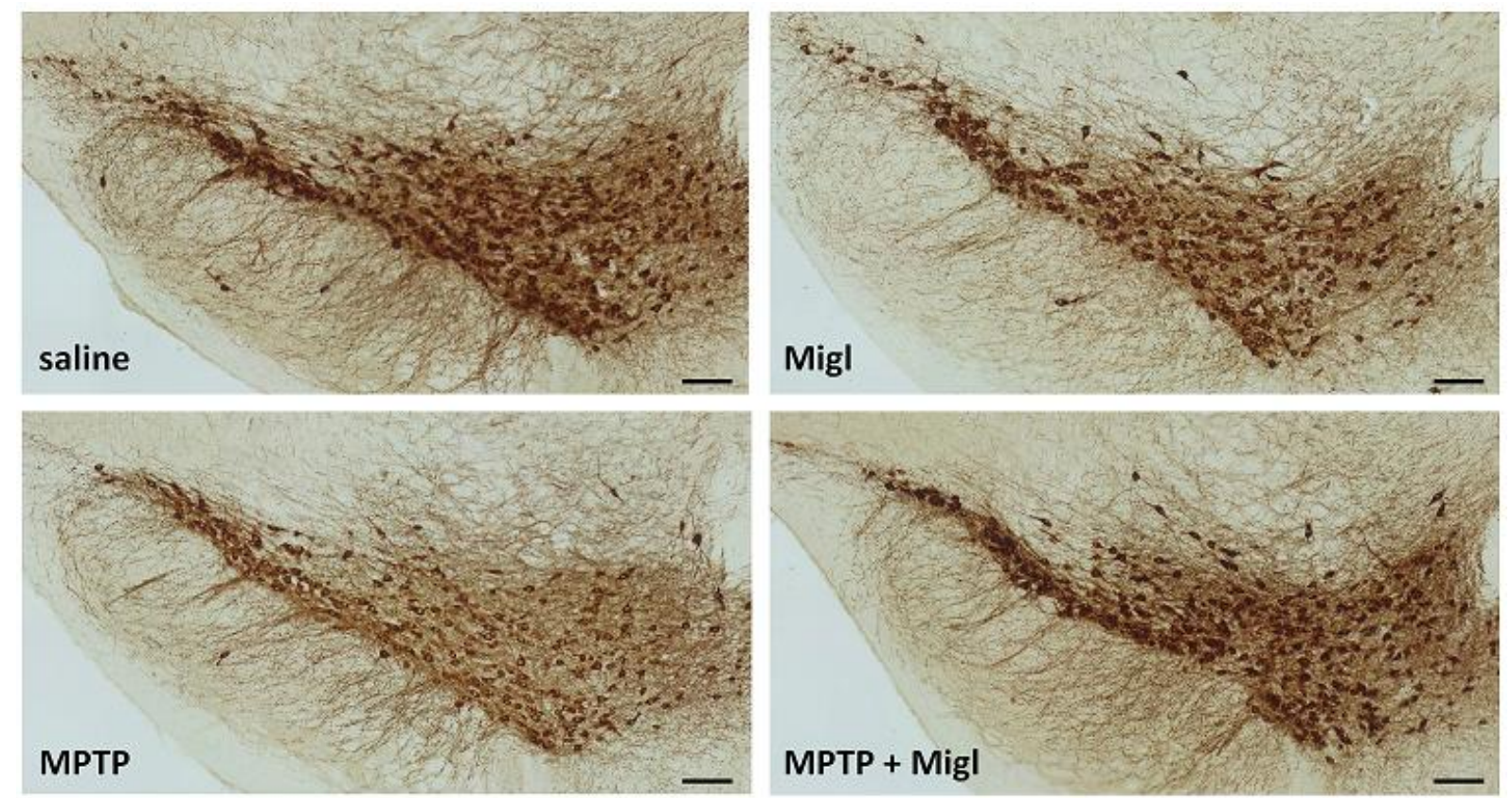

2B: Representative photographs of the SNpc (TH staining) of each treatment group. Note the reduced number of $\mathrm{TH}+$ cells in the SNpc after MPTP intoxication compared to control; miglustat attenuated MPTP-induced cell loss. Magnification: 20x; Scale bar: $50 \mu \mathrm{m}$. 
Figure 3: Striatal dopamine concentrations and HVA/DA ratios are unaffected by miglustat treatment
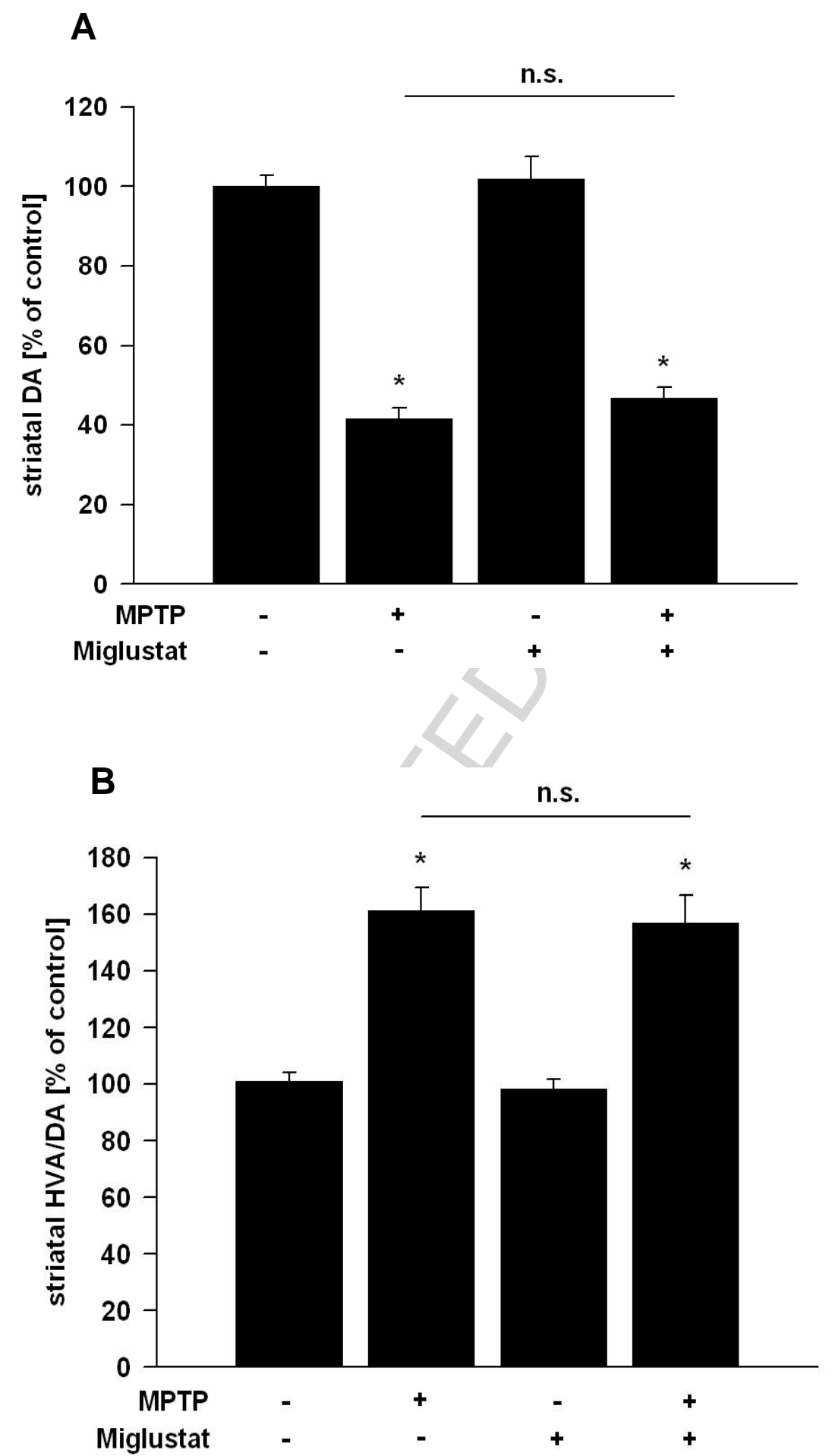

Effects of miglustat treatment on striatal neurotransmitter levels after MPTP intoxication (A: DA; B: HVA/DA ratio). Data are expressed as the percent of corresponding control values. Each data point represents mean \pm S.E.M. ( ${ }^{*} p<0.05$, compared to control values). 


\subsection{GCase inhibition enhances $\mathrm{MPP}^{+}$toxicity in vitro}

Next, we tested the effect of GCase inhibition on MPP ${ }^{+}$-induced toxicity in vitro. Primary mesencephalic cell cultures were treated with different concentrations of CBE (50-400 $\mu \mathrm{M})$ : this treatment did not alter $\mathrm{TH}+$ cell number at concentration of 50-200 $\mu \mathrm{M}$ (Fig. 4A). Cultures were then treated with $\mathrm{MPP}^{+}(1 \mu \mathrm{M})$ : $\mathrm{TH}+$ cell loss under these conditions was $80.2 \pm 0.8 \%$. When CBE was added, TH+ cell number further decreased by $8.1 \pm 0.8 \%$ (Fig. 4B). These results show that $\mathrm{CBE}$ is devoid of intrinsic toxic properties on $\mathrm{TH}+$ neurons in primary mesencephalic cell cultures, but is able to potentiate the toxic effects of MPP ${ }^{+}$. Miglustat did not protect against $\mathrm{MPP}^{+}$toxicity alone; however, miglustat was able to counteract $\mathrm{CBE}-$ enhanced toxicity of $\mathrm{MPP}^{+}$(Fig. 4C).

\section{Figure 4:}

\section{A CBE $(50-200 \mu \mathrm{M})$ does not alter the number of $\mathrm{TH}+$ cells}

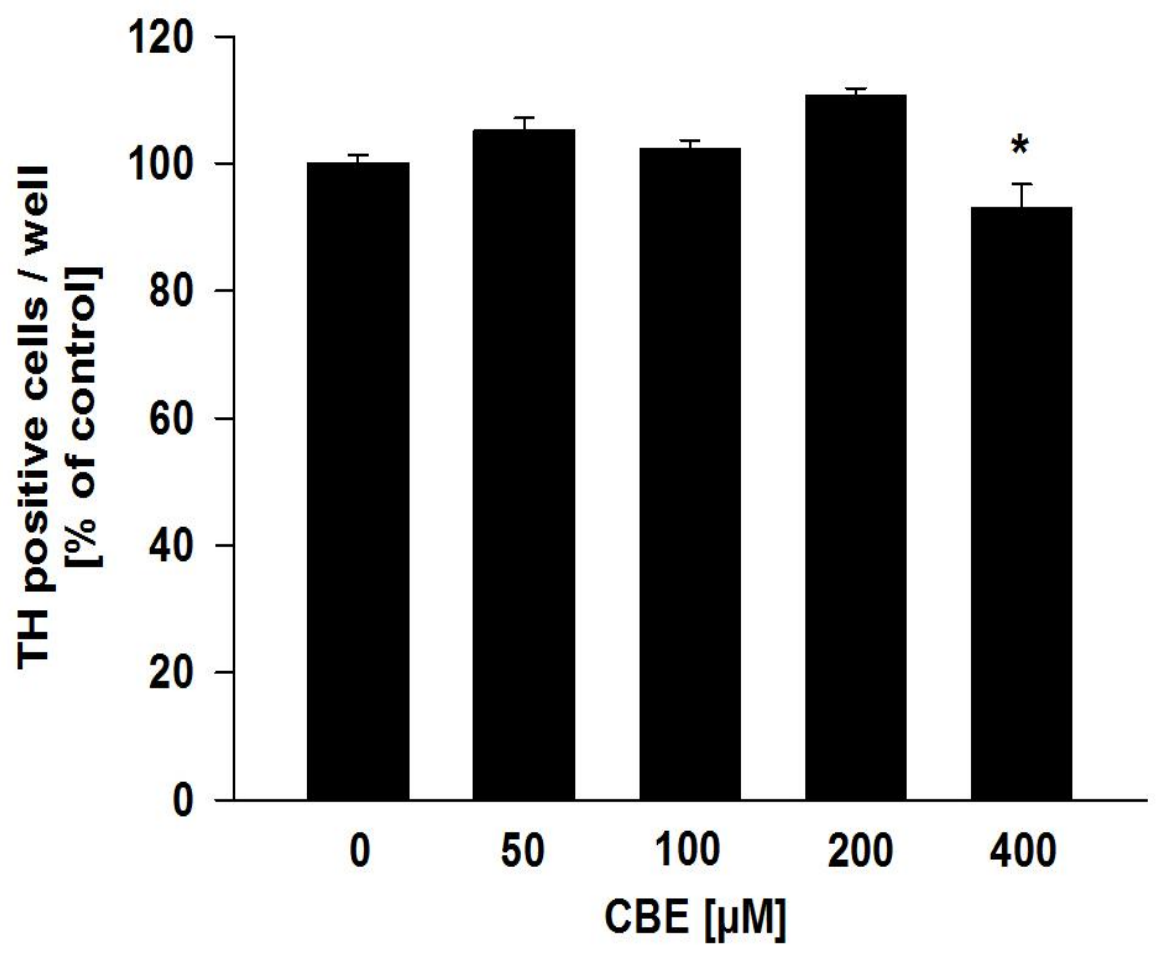


B

$$
\text { CBE causes increased MPP }{ }^{+} \text {toxicity }
$$

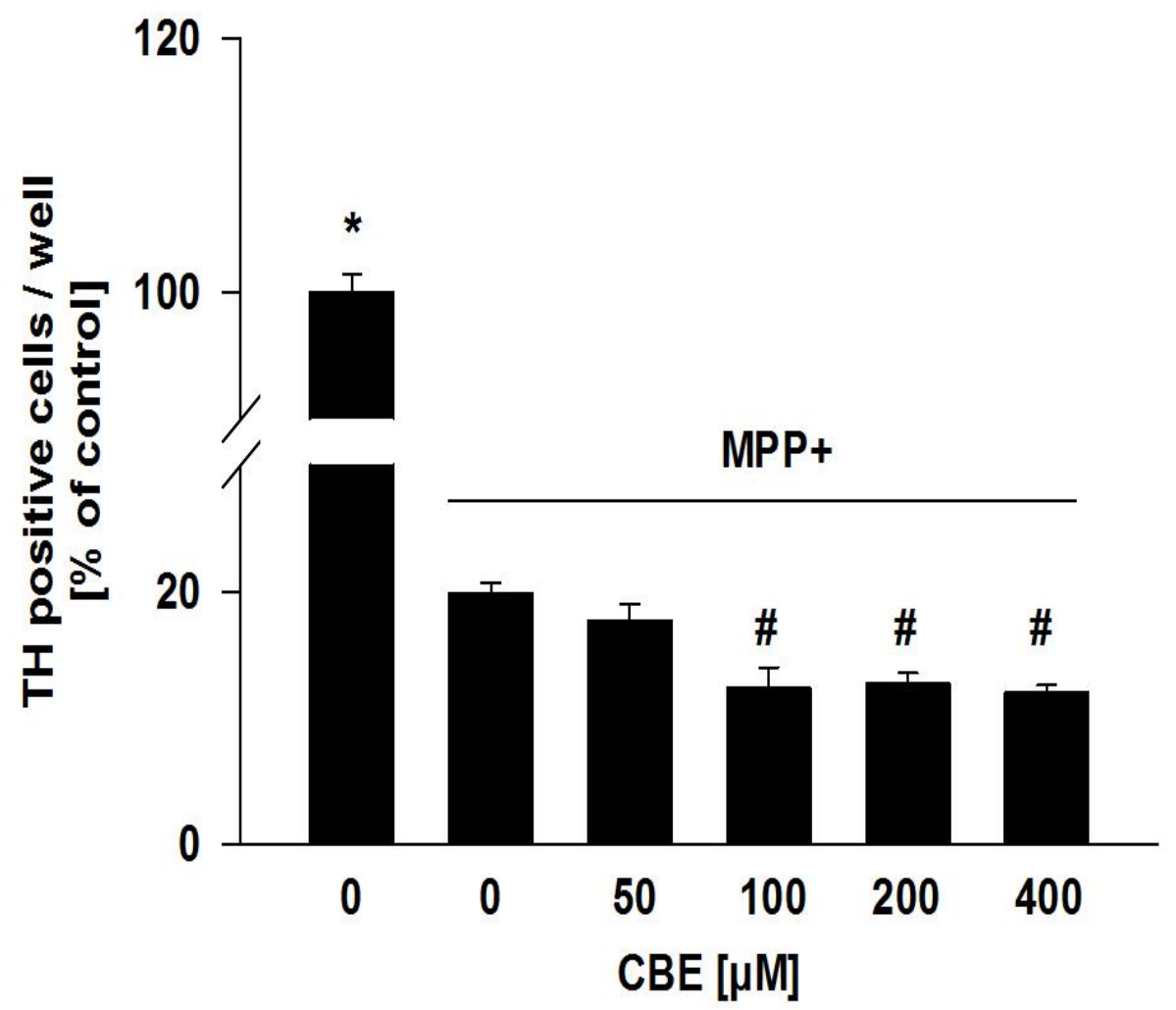

C

Miglustat is able to counteract CBE-enhanced toxicity of MPP ${ }^{+}$

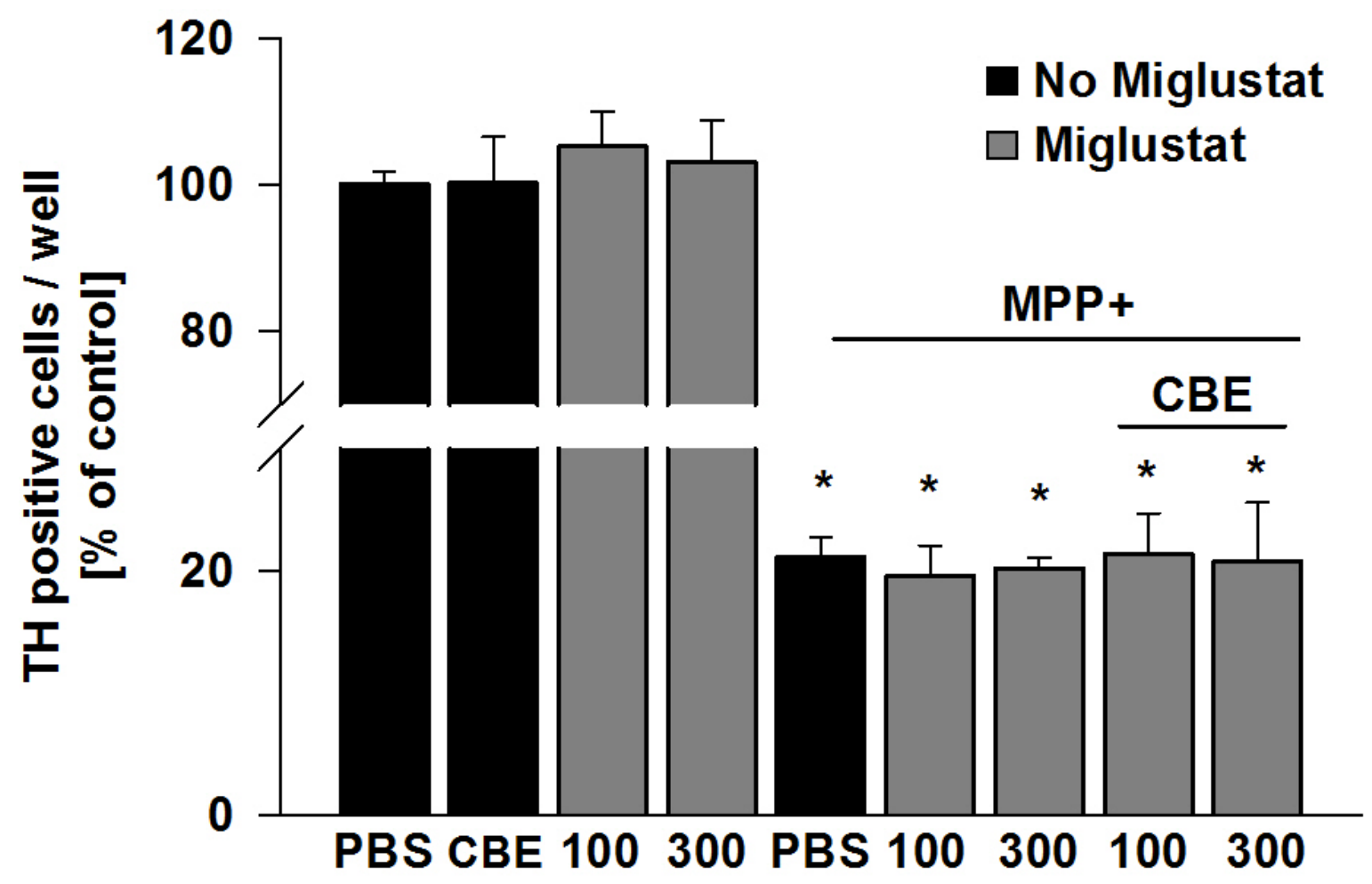


Effects of CBE, a GCase inhibitor, on the survival of TH-positive cells in vitro in the absence (A) or presence (B) of $\mathrm{MPP}^{+}$and the effect of co-treatment with miglustat (C).

A: First, CBE was used in different concentrations (50-400 $\mu \mathrm{M})$ on primary mecencephalic cultures. Only at a concentration of $400 \mu \mathrm{M}$ a significant decrease of $\mathrm{TH}+$ neurons were detectable $\left({ }^{*} \mathrm{p}<0.05\right.$ compared to control values).

B: $\mathrm{TH}+$ cell loss after $\mathrm{MPP}^{+}$treatment $(1 \mu \mathrm{M})$ was $80.2 \pm 0.8 \%$.Co-treatment with CBE $(50-400 \mu \mathrm{M})$ causes an increased $\mathrm{MPP}^{+}$toxicity $\left({ }^{*} p<0.05\right.$ compared to control values, $\# p<0.05$ for pairwise comparison comparted to $\mathrm{MPP}^{+}$without $\mathrm{CBE}$ ).

C: $\mathrm{TH}+$ cell loss after MPP ${ }^{+}$treatment $(1 \mu \mathrm{M})$ was $80.2 \pm 0.8 \%\left({ }^{*} \mathrm{p}<0.05\right.$ compared to PBS control). Treatment of miglustat at a concentration of 100 and $300 \mu \mathrm{M}$, respectively did not protect against

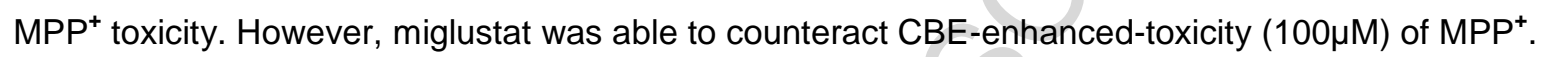

Data are expressed as the percent of corresponding control values ( $\mathrm{TH}+$ cells per well in $\%$ of control, control $=100 \%=257$ cells $/$ well). Each data point represents mean \pm S.E.M $\left({ }^{*} p<0.05\right.$ compared to PBS control values).

\section{3 $\alpha$-Syn enhances toxicity of GCase inhibition in vitro}

It is known that a reduction in GCase activity leads to an accumulation of $\alpha$-Syn in neuroblastoma cells [13-15]. Therefore, we wanted to test whether GCase inhibition by conduritol-B-epoxide (CBE) would increase toxicity in a-Syn-overexpressing LUHMES cells, a human dopaminergic neuronal cell line. Overexpression of $\alpha$-Syn led to significant cell death (set as $100.0 \% \pm 3.9$, $\alpha$-Syn) compared to occasional occurring cell death in untreated controls $(9.3 \% \pm 0.8$, PBS). Whereas $\mathrm{CBE}$ alone at $800 \mu \mathrm{M}$ did not lead to altered cell survival $(9.3 \% \pm 0.7)$, $\alpha$-Syn induced toxicity was further enhanced by co-treatment with CBE in a dose dependent manner $(111.7 \% \pm 5.4$ with $400 \mu \mathrm{M}$ and $129.2 \% \pm 4.9$ with $800 \mu \mathrm{M}$, Fig. 5A).

Next, we tested whether inhibition of glucosylceramide synthase by miglustat might protect against $\alpha$-Syn toxicity. Overexpression of $\alpha$-Syn in LUHMES cells led to significant cell death (set as $100 \% \pm 5.0$, a-Syn ) compared to occasional occurring cell death in untreated controls $(10.4 \% \pm 1.0$, PBS; and $9.1 \pm 0.7$ in miglustat-treated controls, respectively). Co-treatment with miglustat could not reduce $\alpha$-Syn-induced toxicity $(99.0 \% \pm$ 4.3 (miglustat $50 \mu \mathrm{M}$ ) and 98.8\% \pm 5.1 (miglustat $100 \mu \mathrm{M}$, Fig. 5B). Similarly, when $\alpha-S y n-$ overexpressing LUHMES cells were treated by CBE, no protective effect of miglustat was 
detectable, whereas a-Syn overexpression led to cell toxicity in the same range as in prior experiments $(100.0 \% \pm 2.9$ compared to $6.3 \% \pm 0.3$ in control conditions). Addition of $\mathrm{CBE}$ increased toxicity to $117.8 \% \pm 4.6(400 \mathrm{nM})$ and $132.3 \% \pm 9.4(800 \mathrm{nM})$. Co-treatment with miglustat did not alter this toxicity $(133.7 \% \pm 4.0$ and $136.7 \pm 2.9$, respectively) (Fig. 5C).

Figure 5 :

A GCase inhibition by CBE causes increased toxicity of $\alpha$-Syn

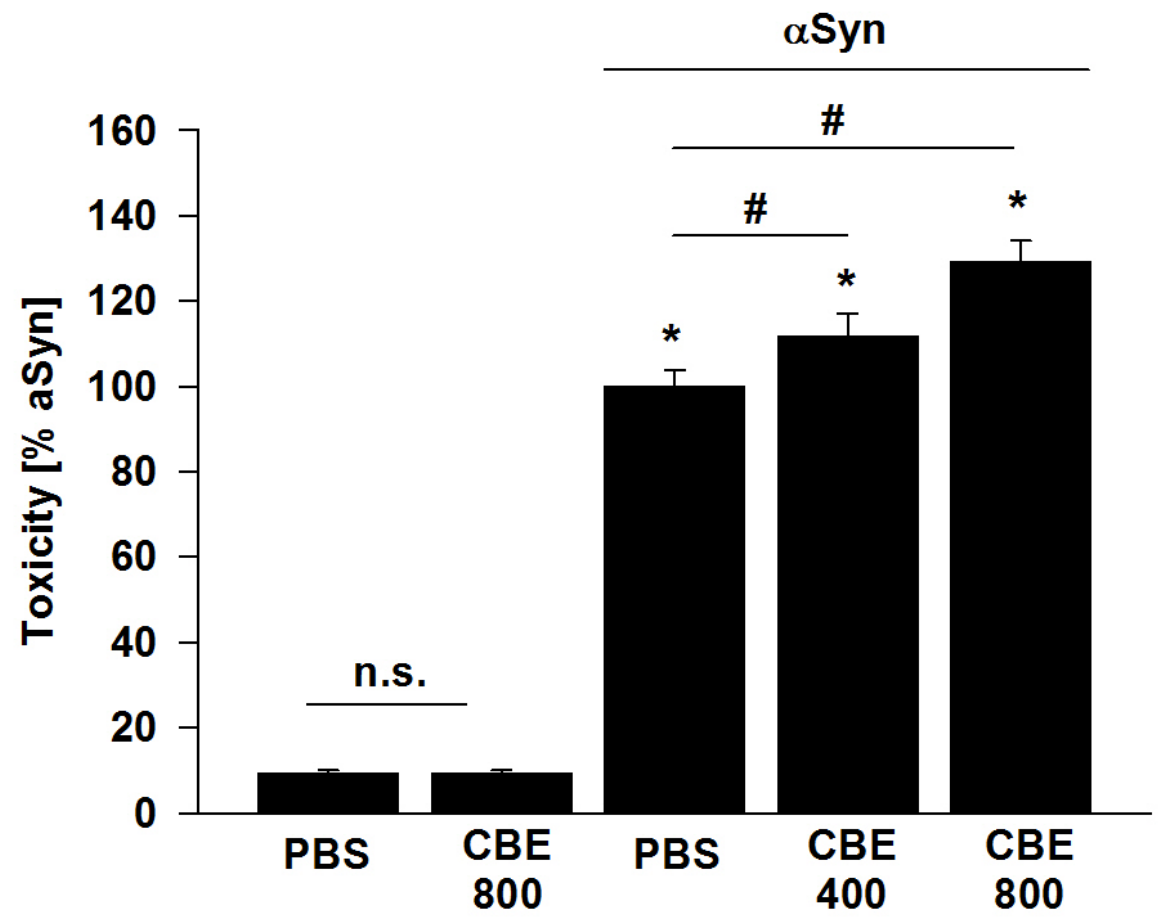




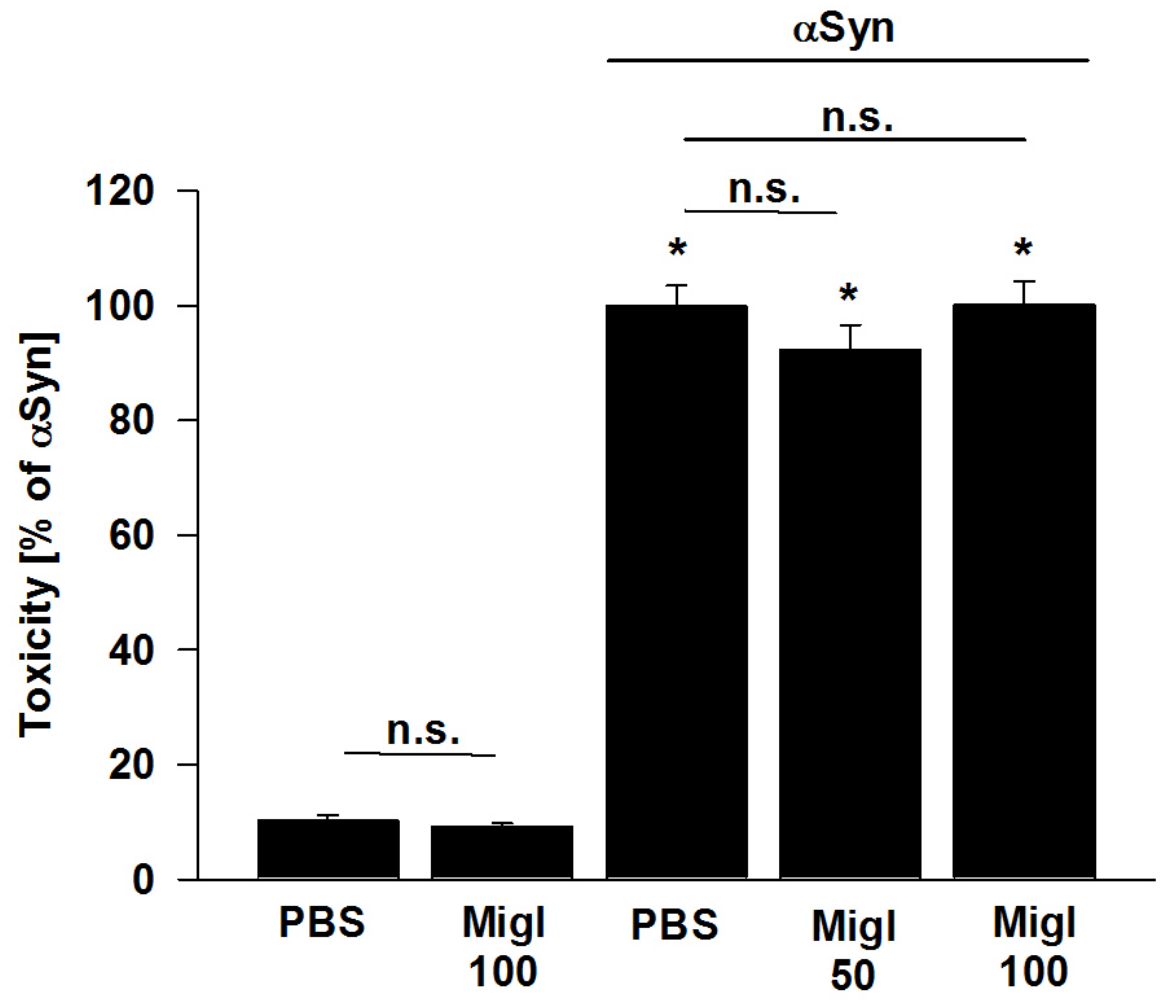

C Co-treatment of miglustat does not alter the effect of CBE on a-Syn toxicity

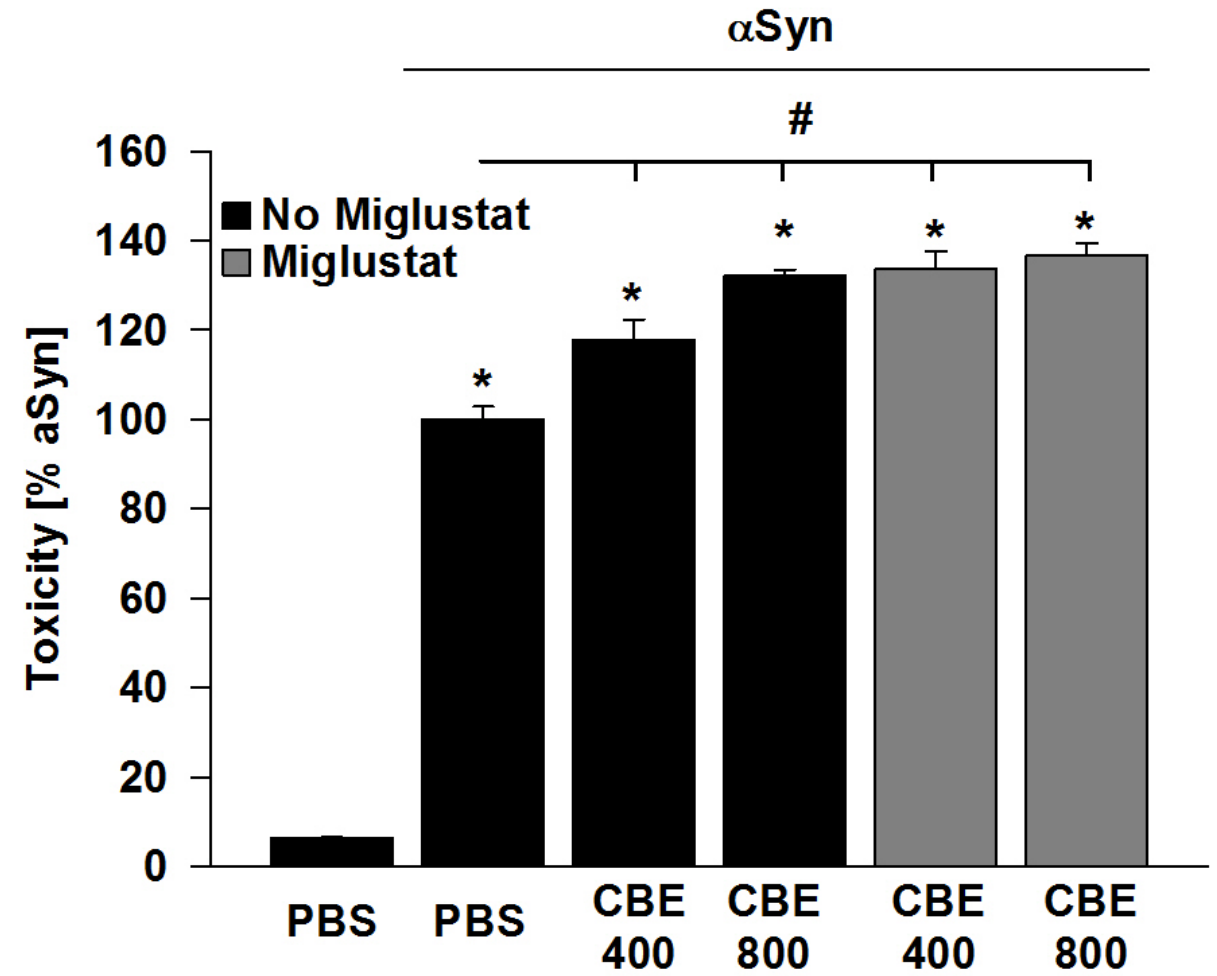


Effects of conduritol-B-epoxide (CBE 400 and $800 \mu \mathrm{M}$ ) (A) and miglustat (Migl 50 and $100 \mu \mathrm{M}$ ) (B) on $\alpha$-Syn induced toxicity in LUHMES cells overexpressing human WT $\alpha$-Syn (aSyn) or untransduced cells.

Data are expressed as percent of corresponding values of $\alpha$-Syn overexpressing cells and represent mean \pm S.E.M. ${ }^{*} p<0.05$ compared to control values, $\# p<0.05$ for pairwise comparison. 


\subsection{No alterations of complex I activity or cell respiration upon treatment with either CBE or miglustat in vitro}

We tested the cell energy metabolism by measuring the oxygene consumption rate (OCR) for the aerobic and the extracellular proton production (extracellular acidification rate, ECAR) of the glycolytic pathway. Since primary mesencephalic cultures contain only about $1-3 \%$ of dopaminergic neurons $\left(\mathrm{TH}^{+}\right)$[32], we carried out the tests on a dopaminergic cell line, $\mathrm{SH}$ SY5Y cells. Neither the inhibition of GCase by CBE $(800 \mu \mathrm{M})$ nor the inhibition of glucosylceramide synthase by miglustat $(100 \mu \mathrm{M})$ altered complex I activity in these cells compared to controls (Fig 6A). Whereas the oxygen consumption was lowered by oligomycin and increased by CCCP, neither the inhibition of GCase by CBE $(800 \mu \mathrm{M})$ nor the inhibition of glucosylceramide synthase by miglustat $(100 \mu \mathrm{M})$ altered the respiratory chain under basal conditions, stress and complete inhibition (Fig 6B) supporting the findings on complex I activity. Also, the glycolytic pathway, measured by by the extracellular $\mathrm{pH}$ indicated by the ECAR, was comparable among all treatment conditions (Fig 6C) suggesting that neither the inhibition of GCase nor of glucosylceramide synthase have an impact on cellular energy metabolism in this experimental set up. 
Figure 6 :
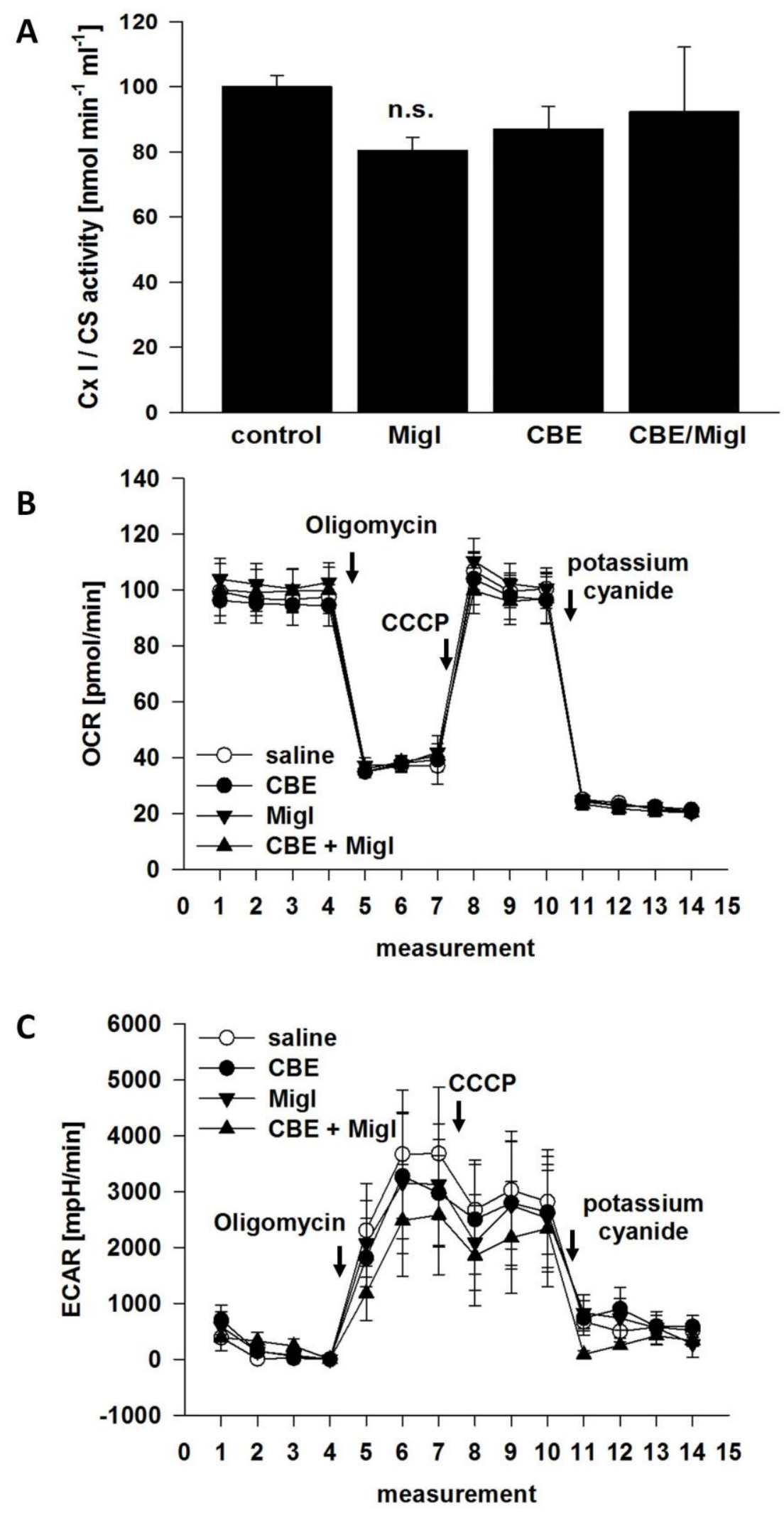
Effects of CBE $(800 \mu \mathrm{M})$ and/or miglustat $(100 \mu \mathrm{M})$ on complex I activity or cell respiration. Mitochondrial respiratory chain complex I (Cx I) and citrate synthase (CS) activity were measured (A). Data were expressed as ratios of Cx I/CS activity in \% of control. Cell respiration and glycolytic pathway indicated oxygen consumption rate $(\mathrm{OCR})(\mathrm{B})$ and the extracellular acidification rate $(\mathrm{ECAR})$ (C), after sequential treatment with oligomycin (ATPase inhibitor), CCCP (carbonyl cyanide 4(trifluoromethoxy)-phenylhydrazone) an uncoupler to show maximal respiration, and potassium cyanide to show nonmitochondrial oxygen consumption. Data are expressed as \% of baseline. 


\section{Discussion}

Our results support a link between GCase activity and sporadic PD. We demonstrate that MPTP toxicity in mice can be diminished by decreasing glucocerebroside, the substrate accumulating when GCase activity is reduced. In addition, we show that GCase inhibition potentiates the toxic effects of MPP ${ }^{+}$-induced toxicity on primary mesencephalic cell cultures. This GCase-related toxicity is blocked by treatment with miglustat. Moreover, we show that GCase inhibition by CBE causes an increased toxicity in $\alpha$-Syn-overexpressing LUHMES cells, a human dopaminergic neuronal cell line. In contrast to MPP+-induced toxicity, miglustat does not protect against $\alpha$-Syn toxicity alone or enhanced by CBE. As to a possible mechanism by which CBE or miglustat alter MPP+- and synuclein-induced toxicity, we were unable to reveal any alterations of complex I activity or cell respiration upon treatment with these agents.

To date, available cell culture or mouse models of Gaucher disease have not demonstrated any toxicity on dopaminergic neurons. In vivo, Sardi et al. [33] could show that a mouse model of Gaucher disease (Gba1D409V/D409V) exhibits characteristics of synucleinopathies, including progressive accumulation of proteinase K-resistant $\alpha$ synuclein/ubiquitin aggregates in hippocampal neurons and a coincident memory deficit. However, no cell loss, especially in the SNpc, was reported. In vitro, a recent study has shown that survival of differentiated SH-SY5Y cells treated with CBE $(50-200 \mathrm{mM})$ is not compromised [14]. However, increased expression of a-Syn was observed in cell extracts. In vivo, these authors also treated C57BI/6 mice with a single i.p. dose of $200 \mathrm{mg} / \mathrm{kg} \mathrm{CBE}$ or DMSO (as controls). No data were provided on DA cell numbers in the SNpc but as in vitro, a-Syn concentrations were increased in extracts from ventral mesencephalon (48h survival time). Furthermore, increased $\alpha$-Syn staining could be observed in nigral astrocytes of mice treated with CBE compared to DMSO. Thus, these results indicate that inhibition of GCase activity by CBE increases $\alpha$-Syn levels in vitro and in vitro [14]. More recently, Manning-Bog et al. [34] demonstrated, also in SH-SY5Y cells, that GCase inhibition by CBE $(50 \mu \mathrm{M})$ causes mitochondrial respiratory chain dysfunction, ATP reduction and free radical 
production without, however, causing actual cell death. Also, Manning-Bog et al. and Cleeter et al. $[14,34]$ show that GCase inhibtion increases $\alpha$-Syn protein levels in cell extracts. Both in vitro studies thereby indicate that GCase inhibition by CBE is insufficient to cause cell death in SH-SY5Y cells - a result that we reproduce in primary dopaminergic cultures. Moreover, our data suggest that an additional environmental factor, such as direct complex I inhibition of the mitochondrial respiratory chain by $\mathrm{MPP}^{+}$in conjunction with reduced GCase activity may be necessary to elicit actual cell death.

Mazzuli and colleagues [11] provide a potential mechanistic link between Gaucher disease and PD. They showed that loss of GCase activity in primary neuronal cultures and in human neurons derived from induced pluripotent stem cells from a Gaucher disease patient causes preferential accumulation of $\alpha$-Syn by interfering with its degradation in lysosomes. What is special about these results is that they reveal a bidirectional positive feedback loop in which a-Syn inhibits GCase activity and reduction in GCase activity boosts $\alpha$-Syn accumulation [35]. Such homeostatic processes that keep the feedback loops in check may fail with time, supporting age as the major risk factor in neurodegenerative diseases. With regard to sporadic $\mathrm{PD}$, this means that even in the absence of GBA mutations, $\alpha$-Syn accumulation can affect GCase function. It is well established that $\alpha$-Syn is involved in mediating the toxic effects of MPTP as mice deleted for $\alpha$-Syn are less sensitive to MPTP $[19,36,37]$. A plausible mechanism for the toxic effects of $\alpha$-Syn figures an increase MPTPinduced oxidative stress $[38,39]$. This in turn could provide an explaination why miglustat is effective against MPTP toxicity in vivo despite the absence of GBA mutations. It is also the most likely explanation for the differing in vivo and in vitro results regarding the protective effects of miglustat when administered with MPTP or $\mathrm{MPP}^{+}$alone. Indeed, the kinetics of intoxication are very different in both conditions: subchronic in vivo versus acute in vitro. We postulate that in the latter, there might not be sufficient time for build-up of $\alpha$-Syn and GCase inhibition, for which reason miglustat cannot exert any protective effect. 
It has been reported that Gcase dysfunction results in an accumulation of dysfunctional mitochondria due to defects in both protein and organellar degradation machinery $[34,40]$. Thus, and in light of the mitochondrial actions of MPTP/MPP ${ }^{+}$, we wondered whether a direct inhibition of GCase or a reduction of glucosylceramide by miglustat would lead to alterations in complex I activity or cell respiration and energy metabolism. However, we were unable to reveal any alterations of complex I activity or cell respiration following treatment with either CBE or miglustat. This difference to previous studies could be explained by an acute inhibition of the enzyme compared to an accumulated deficit in GBA-mutated or -deleted cells, as previously discussed [34, 40]. Thus, we conclude that the previously reported effects on cell respiration and complex I activity is an indirect consequence of GCase dysfunction, resulting in impaired mitochondrial degradation and increase of oxidative stress rather than a direct effect of GCase dysfunction or glucosylceramide accumulation.

To summarize, we find that deleterious effects of mitochondrial dysfunction mediated by MPTP or $\mathrm{MPP}^{+}$can be partially rescued by reduction of glucocerebroside and is aggravated by GCase inhibition. In contrast, reduction of glucocerebroside is without effect on $\alpha$-Syn induced toxicity, but this toxicity is aggravated by GCase inhibition. This suggests that enhanced $\alpha$-Syn toxicity is favored by reduced GCase activity rather than glucocerebroside accumulation.

Acknowlegdements : C.N. was supported by a postdoctoral grant from the Deutsche Forschungsgemeinschaft (DFG; NO769/1-1). D.A.F. was funded by the University of Luebeck and the University Medical Center Giessen and Marburg (UKGM). L. L. received a grant from Tongji University, Shanghai, PRC. R.R. is an employee of Actelion Pharmaceuticals, Switzerland. M.H. was funded by the German National Genome Research Network (01GS08136-4). G. H. was funded by the Deutsche Forschungsgemeinschaft (DFG; HO2402/6-1). E.C.H. is an investigator at the Centre National pour la Recherche Scientifique (CNRS). This work was funded by a grant from Actelion Pharmaceuticals Ltd. 
Conflict of interest: This work was funded by a grant from Actelion Pharmaceuticals Ltd., of whom R. R. is an employee, but the funders had no part in the design or analysis of the experiments. The other authors have no conflict of interest to report. 


\section{REFERENCES}

1. Grabowski GA: Gaucher's disease. Enzyme therapy is not enough. Lancet 2001, 358 Suppl:S29.

2. Baba M, Nakajo S, Tu PH, Tomita T, Nakaya K, Lee VM, Trojanowski JQ, Iwatsubo T: Aggregation of alpha-synuclein in Lewy bodies of sporadic Parkinson's disease and dementia with Lewy bodies. Am J Pathol 1998, 152:879-884.

3. Spillantini MG, Crowther RA, Jakes R, Hasegawa M, Goedert M: alpha-Synuclein in filamentous inclusions of Lewy bodies from Parkinson's disease and dementia with lewy bodies. Proc Natl Acad Sci U S A 1998, 95:6469-6473.

4. Sidransky E, Nalls MA, Aasly JO, Aharon-Peretz J, Annesi G, Barbosa ER, Bar-Shira A, Berg $\mathrm{D}$, Bras $\mathrm{J}$, Brice $\mathrm{A}$, et al: Multicenter analysis of glucocerebrosidase mutations in Parkinson's disease. N Engl J Med 2009, 361:1651-1661.

5. Lesage S, Anheim M, Condroyer C, Pollak P, Durif F, Dupuits C, Viallet F, Lohmann E, Corvol JC, Honore A, et al: Large-scale screening of the Gaucher's disease-related glucocerebrosidase gene in Europeans with Parkinson's disease. Hum Mol Genet 2011, 20:202-210.

6. Aharon-Peretz J, Rosenbaum H, Gershoni-Baruch R: Mutations in the glucocerebrosidase gene and Parkinson's disease in Ashkenazi Jews. N Engl J Med 2004, 351:1972-1977.

7. DePaolo J, Goker-Alpan O, Samaddar T, Lopez G, Sidransky E: The association between mutations in the lysosomal protein glucocerebrosidase and parkinsonism. Mov Disord 2009, 24:1571-1578.

8. Anheim M, Elbaz A, Lesage S, Durr A, Condroyer C, Viallet F, Pollak P, Bonaiti B, BonaitiPellie C, Brice A: Penetrance of Parkinson disease in glucocerebrosidase gene mutation carriers. Neurology 2012, 78:417-420.

9. Neumann J, Bras J, Deas E, O'Sullivan SS, Parkkinen L, Lachmann RH, Li A, Holton J, Guerreiro R, Paudel R, et al: Glucocerebrosidase mutations in clinical and pathologically proven Parkinson's disease. Brain 2009, 132:1783-1794.

10. Gegg ME, Burke D, Heales SJ, Cooper JM, Hardy J, Wood NW, Schapira AH: Glucocerebrosidase deficiency in substantia nigra of parkinson disease brains. Ann Neurol 2012, 72:455-463.

11. Mazzulli JR, Xu YH, Sun Y, Knight AL, McLean PJ, Caldwell GA, Sidransky E, Grabowski GA, Krainc D: Gaucher disease glucocerebrosidase and alpha-synuclein form a bidirectional pathogenic loop in synucleinopathies. Cell 2011, 146:37-52.

12. Siebert $M$, Sidransky $E$, Westbroek $W$ : Glucocerebrosidase is shaking up the synucleinopathies. Brain 2014, 137:1304-1322.

13. Bae EJ, Yang NY, Lee C, Lee HJ, Kim S, Sardi SP, Lee SJ: Loss of glucocerebrosidase 1 activity causes lysosomal dysfunction and alpha-synuclein aggregation. Exp Mol Med 2015, 47:e153.

14. Manning-Bog AB, Schule B, Langston JW: Alpha-synuclein-glucocerebrosidase interactions in pharmacological Gaucher models: a biological link between Gaucher disease and parkinsonism. Neurotoxicology 2009, 30:1127-1132.

15. Uemura $N$, Koike $M$, Ansai $S$, Kinoshita $M$, Ishikawa-Fujiwara $T$, Matsui $H$, Naruse K, Sakamoto N, Uchiyama Y, Todo T, et al: Viable Neuronopathic Gaucher Disease Model in Medaka (Oryzias latipes) Displays Axonal Accumulation of Alpha-Synuclein. PLOS Genet 2015, 11:e1005065.

16. Ficicioglu C: Review of miglustat for clinical management in Gaucher disease type 1. Ther Clin Risk Manag 2008, 4:425-431.

17. Dauer W, Przedborski S: Parkinson's disease: mechanisms and models. Neuron 2003, 39:889-909.

18. Przedborski S, Jackson-Lewis V, Djaldetti R, Liberatore G, Vila M, Vukosavic S, Almer G: The parkinsonian toxin MPTP: action and mechanism. Restor Neurol Neurosci 2000, 16:135142.

19. Alvarez-Fischer D, Guerreiro S, Hunot S, Saurini F, Marien M, Sokoloff P, Hirsch EC, Hartmann A, Michel PP: Modelling Parkinson-like neurodegeneration via osmotic minipump delivery of MPTP and probenecid. $J$ Neurochem 2008, 107:701-711.

20. Hirsch E, Graybiel AM, Agid YA: Melanized dopaminergic neurons are differentially susceptible to degeneration in Parkinson's disease. Nature 1988, 334:345-348.

21. Alvarez-Fischer D, Fuchs J, Castagner F, Stettler O, Massiani-Beaudoin O, Moya KL, Bouillot $\mathrm{C}$, Oertel $\mathrm{WH}$, Lombes $\mathrm{A}$, Faigle $\mathrm{W}$, et al: Engrailed protects mouse midbrain 
dopaminergic neurons against mitochondrial complex I insults. Nat Neurosci 2011, 14:1260-1266.

22. Franklin $\mathrm{KBJaP}$, George The mouse brain in stereotaxic coordinates. Book (ISBN 0122660706 ) 1997.

23. Brugg B, Michel PP, Agid Y, Ruberg M: Ceramide induces apoptosis in cultured mesencephalic neurons. J Neurochem 1996, 66:733-739.

24. Salthun-Lassalle B, Hirsch EC, Wolfart J, Ruberg M, Michel PP: Rescue of mesencephalic dopaminergic neurons in culture by low-level stimulation of voltage-gated sodium channels. J Neurosci 2004, 24:5922-5930.

25. Mourlevat S, Troadec JD, Ruberg M, Michel PP: Prevention of dopaminergic neuronal death by cyclic AMP in mixed neuronal/glial mesencephalic cultures requires the repression of presumptive astrocytes. Mol Pharmacol 2003, 64:578-586.

26. Michel PP, Dandapani BK, Knusel B, Sanchez-Ramos J, Hefti F: Toxicity of 1-methyl-4phenylpyridinium for rat dopaminergic neurons in culture: selectivity and irreversibility. J Neurochem 1990, 54:1102-1109.

27. Hollerhage M, Goebel JN, de Andrade A, Hildebrandt T, Dolga A, Culmsee C, Oertel WH, Hengerer B, Hoglinger GU: Trifluoperazine rescues human dopaminergic cells from wildtype alpha-synuclein-induced toxicity. Neurobiol Aging 2014, 35:1700-1711.

28. Pesta D, Gnaiger E: High-resolution respirometry: OXPHOS protocols for human cells and permeabilized fibers from small biopsies of human muscle. Methods Mol Biol 2012, 810:25-58.

29. Noelker C, Schwake M, Balzer-Geldsetzer M, Bacher M, Popp J, Schlegel J, Eggert K, Oertel WH, Klockgether T, Dodel RC: Differentially expressed gene profile in the 6-hydroxydopamine-induced cell culture model of Parkinson's disease. Neurosci Lett 2012, 507:1015.

30. Alvarez-Fischer D, Noelker C, Grunewald A, Vulinovic F, Guerreiro S, Fuchs J, Lu L, Lombes A, Hirsch EC, Oertel WH, et al: Probenecid potentiates MPTP/MPP+ toxicity by interference with cellular energy metabolism. J Neurochem 2013, 127:782-792.

31. Grunewald A, Voges L, Rakovic A, Kasten M, Vandebona H, Hemmelmann C, Lohmann K, Orolicki S, Ramirez A, Schapira AH, et al: Mutant Parkin impairs mitochondrial function and morphology in human fibroblasts. PLoS One 2010, 5:e12962.

32. Michel PP, Ruberg M, Agid Y: Rescue of mesencephalic dopamine neurons by anticancer drug cytosine arabinoside. J Neurochem 1997, 69:1499-1507.

33. Sardi SP, Clarke J, Kinnecom C, Tamsett TJ, Li L, Stanek LM, Passini MA, Grabowski GA, Schlossmacher MG, Sidman RL, et al: CNS expression of glucocerebrosidase corrects alpha-synuclein pathology and memory in a mouse model of Gaucher-related synucleinopathy. Proc Natl Acad Sci U S A 2011, 108:12101-12106.

34. Cleeter MW, Chau KY, Gluck C, Mehta A, Hughes DA, Duchen M, Wood NW, Hardy J, Mark Cooper J, Schapira AH: Glucocerebrosidase inhibition causes mitochondrial dysfunction and free radical damage. Neurochem Int 2013, 62:1-7.

35. Dawson TM, Dawson VL: A lysosomal lair for a pathogenic protein pair. Sci Transl Med 2011, 3:91ps28.

36. Drolet RE, Behrouz B, Lookingland KJ, Goudreau JL: Mice lacking alpha-synuclein have an attenuated loss of striatal dopamine following prolonged chronic MPTP administration. Neurotoxicology 2004, 25:761-769.

37. Schluter OM, Fornai F, Alessandri MG, Takamori S, Geppert M, Jahn R, Sudhof TC: Role of alpha-synuclein in 1-methyl-4-phenyl-1,2,3,6-tetrahydropyridine-induced parkinsonism in mice. Neuroscience 2003, 118:985-1002.

38. Alvarez-Fischer D, Henze C, Strenzke C, Westrich J, Ferger B, Hoglinger GU, Oertel WH, Hartmann A: Characterization of the striatal 6-OHDA model of Parkinson's disease in wild type and alpha-synuclein-deleted mice. Exp Neurol 2008, 210:182-193.

39. Klivenyi P, Siwek D, Gardian G, Yang L, Starkov A, Cleren C, Ferrante RJ, Kowall NW, Abeliovich A, Beal MF: Mice lacking alpha-synuclein are resistant to mitochondrial toxins. Neurobiol Dis 2006, 21:541-548.

40. Osellame LD, Rahim AA, Hargreaves IP, Gegg ME, Richard-Londt A, Brandner S, Waddington SN, Schapira AH, Duchen MR: Mitochondria and quality control defects in a mouse model of Gaucher disease--links to Parkinson's disease. Cell Metab 2013, 17:941-953. 
Highlights "Glucocerebrosidase deficiency and mitochondrial impairment in experimental Parkinson disease":

- Inhibition of glucosylceramide synthase partially protects mice against subchronic MPTP intoxication

- in vitro a decrease of GCase activity may render dopaminergic neurons susceptible to $\mathrm{MPP}^{+}$

- in vitro a decrease of GCase activity may render dopaminergic neurons susceptible to $\alpha$-Syn toxicity

- Results suggest an interference of glucocerebroside activity in nigral dopaminergic cell death 